\title{
PENGARUH CITRA MEREK TERHADAP KEPUTUSAN PEMBELIAN MELALUI PERSEPSI KONSUMEN PADA PT. PERMATA MOTOR YAMAHA JATIBARANG
}

\author{
The Effect Of Brand Images On Purchase Decisions Through \\ Consumer Perception In PT. Permata Motor Yamaha Jatibarang
}

\author{
Nandan A Hidayat, M.Arif Hasan \\ Manajemen FE Unversitas Wiralodra \\ Nandanhidayat@gmail.com
}

\begin{abstract}
ABSTRAK
Hasil analisis korelasi citra merek terhadap persepsi konsumen adalah korelasi r12 = 0,429 membuktikan bahwa terdapat pengaruh citra merek terhadap persepsi konsumen dengan kategori sedang. Hasil analisis determinasinya adalah $\mathrm{Kd}=\mathbf{1 8 , 4 0 \%}$ berarti citra merek memiliki kontribusi terhadap persepsi konsumen sebesar $18,40 \%$ Sedangkan sisanya $81,60 \%$ dipengaruhi oleh faktor-faktor lainnya yang tidak diteliti. Dan hasil uji hipotesisnya adalah th $=3,829$ sedangkan $t$ tabel dengan taraf keyakinan $5 \%$ dan derajat kebebasan $\mathrm{dk}=\mathrm{n}-2=67-2=65$, maka $\mathrm{t}$ hitung $=3,829$ Karena $t$ hitung lebih besar dari $t$ tabel yaitu sebesar $(3,829>1,997)$, maka Ha diterima dan Ho ditolak, artinya "ada pengaruh citra merek terhadap persepsi konsumen. Hasil analisis korelasi antara persepsi konsumen dengan keputusan pembelian adalah korelasi r2y $=0,392$ membuktikan bahwa terdapat pengaruh persepsi konsumen terhadap keputusan pembelian dengan kategori rendah. Hasil analisis determinasinya adalah $\mathrm{Kd}=\mathbf{2 7 , 6 6 \%}$ berarti persepsi konsumen memiliki kontribusi terhadap keputusan pembelian sebesar $27,66 \%$ Sedangkan sisanya $\mathbf{7 2 , 3 4 \%}$ dipengaruhi oleh faktor-faktor lainnya yang tidak diteliti. Dan hasil uji hipotesisnya adalah th $=3,436$ sedangkan $t$ tabel dengan taraf keyakinan $5 \%$ dan derajat kebebasan $\mathrm{dk}=\mathrm{n}-2=67-2=65$, maka $\mathrm{t}$ table $=3,436$ Karena t hitung lebih besar dari t tabel yaitu sebesar $(3,436>1,997)$, maka Ha diterima dan Ho ditolak, artinya "ada pengaruh keputusan pembelian terhadap persepsi konsumen. Hasil analisis korelasi citra merek terhadap keputusan pembelian melalui motivasi adalah korelasi $\mathbf{r 1 2 y}=$ 0,639 membuktikan bahwa terdapat pengaruh citra merek terhadap keputusan pembelian melalui persepsi konsumen
\end{abstract}

dengan kategori kuat. Hasil analisis determinasinya adalah $\mathrm{Kd}=\mathbf{4 0 , 8 8 \%}$ berarti citra merek terhadap keputusan pembelian melalui persepsi konsumen memiliki kontribusi sebesar $\mathbf{4 0 , 8 8 \%}$ Sedangkan sisanya $59,12 \%$ dipengaruhi oleh faktorfaktor lainnya yang tidak diteliti. Dan hasil uji hipotesisnya adalah th $=6,695$ sedangkan $t$ tabel dengan taraf keyakinan $5 \%$ dan derajat kebebasan $\mathrm{dk}=\mathrm{n}-2=67-2=65$, maka t table $=6,695$ Karena $t$ hitung lebih besar dari t tabel yaitu sebesar $(6,695>1,997)$, maka Ha diterima dan Ho ditolak, artinya "ada pengaruh citra merek terhadap persepsi konsumen melalui keputusan pembelian"

Kata Kunci: Citra Merek, Persepsi Konsumen, Keputusan Pembelian

\section{ABSTRACT}

The results of brand image correlation analysis on consumer perceptions are the correlation $\mathbf{r 1 2}=\mathbf{0 . 4 2 9}$ proving that there is an influence of brand image on consumer perceptions with the medium category. The results of the analysis of determination are Kd $=\mathbf{1 8 . 4 0 \%}$, which means that the brand image has a contribution to consumer perceptions of $18.40 \%$ while the remaining $81.60 \%$ is influenced by other factors not examined. And the results of hypothesis testing are th $=\mathbf{3 . 8 2 9}$ while $t$ table with a confidence level of $5 \%$ and degrees of freedom $d k=n-2=67-2=65$, then $t$ count $=$ 3.829 Because $t$ count is greater than $t$ table that is equal to $(3.829>1,997)$, then $\mathrm{Ha}$ is accepted and Ho is rejected, meaning "there is an influence of brand image on consumer perception. The results of the correlation analysis between consumer perceptions and purchasing decisions are $\mathbf{r} 2 \mathbf{y}$ correlation = 0.392 proving that there is an influence of consumer perceptions of purchasing 
decisions with a low category. The results of the analysis of determination are $\mathrm{Kd}=$ $27.66 \%$, which means that consumer perceptions have a contribution to purchasing decisions of $27.66 \%$ while the remaining $72.34 \%$ is influenced by other factors not examined. And the results of hypothesis testing are th $=3,436$ while $t$ table with a confidence level of $5 \%$ and degrees of freedom $d k=n-2=67-2=65$, then $t$ table $=$ 3,436 Because $t$ count is greater than $t$ table that is equal to $(3,436>1,997)$, then $\mathrm{Ha}$ is accepted and $\mathrm{Ho}$ is rejected, meaning "there is an influence of purchasing decisions on consumer perceptions. The results of brand image correlation analysis on purchasing decisions through motivation is a correlation of $\mathbf{r} 12 \mathrm{y}=\mathbf{0 . 6 3 9}$ proving that there is an influence of brand image on purchasing decisions through consumer perceptions with a strong category. The results of the analysis of determination are $\mathrm{Kd}=\mathbf{4 0 . 8 8 \%}$ means that the brand image of purchasing decisions through consumer perception has a contribution of $\mathbf{4 0 . 8 8 \%}$ while the remaining $59.12 \%$ is influenced by other factors not examined. And the results of the hypothesis test are th $=\mathbf{6 . 6 9 5}$ while $t$ table with a confidence level of $5 \%$ and degrees of freedom $d k=n-2=67-2=65$, then $t$ table $=$ 6.695 Because $t$ count is greater than $t$ table which is equal to $(6.695>1,997)$, then $\mathrm{Ha}$ is accepted and Ho is rejected, meaning "there is an influence of brand image on consumer perceptions through purchasing decisions"

Keywords: Brand Image, Consumer Perception, Purchasing Decision

\section{PENDAHULUAN}

Yamaha mempunyai beberapa merek jenis motor, seperti mio fino, mio J, soul GT, xeon, yamaha x-ride, lexam, vega $z r$, jupiter $\mathrm{z}$, jupiter $\mathrm{mx}$, byson, vixion dan lain-lain. Motor yamaha mempunyai banyak keunggulan antara lain keawetannya, mudahnya mendapatkan suku cadang, mudahnya dalam perawatan, desain yang menarik serta iritnya bahan bakar. Keunggulan teknologi suatu produk mempunyai pengaruh besar terhadap keputusan pembelian, disamping harga, karena dua hal tersebut merupakan alat komunikasi dan arah yang dapat menentukan perilaku serta image sehingga dapat membentuk persepsi bagi konsumen. Menurut Philip Kotler dan Keller (2009:403) menyatakan bahwa, "citra merek adalah persepsi dan keyakinan yang dipegang oleh konsumen, seperti yang dicerminkan asosiasi yang tertanam dalam ingatan konsumen.” Menurut Sumarwan Ujang (2009:21) menyatakan bahwa: Citra merek adalah citra yang dibangun dalam alam bawah sadar konsumen melalui informasi dan ekspektasi yang diharapkan melalui prosuk atau jasa."

Berdasarkan pengertian ahli diatas, dapat disimpulkan bahwa citra merek adalah persepsi dan keyakinan yang dipegang oleh konsumen, yang dibangun dalam alam bawah sadar konsumen melalui informasi dan ekspektasi yang diharapkan melalui prosuk atau jasa.

Indikator Citra Merek Menurut Philip Kotler dan Keller (2009:403) dan 
Nandan A Hidayat, M. Arif Hasan

Sumarwan Ujang (2009:21) barang yang di keluarkannya menyebutkan bahwa, indikator citra merek adalah: Persepsi Konsumen, Keyakinan Konsumen, Alam Bawah Sadar Konsumen Melalui Informasi,.,Ekspektasi Yang Diharapkan Melalui Prosuk Atau Jasa, Asosiasi Yang Tertanam Dalam Ingatan Konsumen. Faktor-faktor yang mempengaruhi Citra Merek, Menurut Schiffman dan Kanuk (2006:135) menyebutkan bahwa, faktor-faktor pembentuk citra merek adalah: Kualitas atau mutu, Dapat di percaya atau diandalkan, Kegunaan atau manfaat Pelayanan, Resiko, Harga, Citra yang di miliki oleh merek itu sendiri. Tujuan Pemberian Merek Menurut Buchari alma (2011:149) menyebutkan bahwa, tujuan pemberian merek adalah: Perusahaan menjamin konsumen bahwa barang yang di beli sungguh berasal dari perusahaannya. Ini adalah untuk meyakini pihak konsumen membeli suatu barang dari merek dan perusahaan yang dikehendakinya, yang cocok dengan seleranya, keinginannya dan juga kemampuannya.

Perusahaan menjamin mutu barang. Dengan adanya merek ini perusahaan menjamin mutu bahwa

berkualitas baik.

Perusahaan memberi nama merek barangnya supaya mudah diingat dan di sebut sehingga konsumen dapat menyebut mereknya saja.

Meningkatkan ekuitas merek, yang memungkinkan memperoleh margin lebih tinggi, memberi kemudahaan dalam mempertahankan kesetiaan konsumen.

Persepsi Konsumen, Hampir semua kejadian di dunia saat ini penuh dengan rangsangan. Suatu rangsangan itu (stimulus) adalah sebuah unit input yang merangsang satu atau lebih dari lima pancaindra: penglihatan, penciuman, rasa, sentuhan, dan pendengaran. Orang tidak dapat menerima seluruh rangsangan yang ada di lingkungan mereka. Oleh karena itu, mereka mempergunakan keterbukaan yang selektif (selective exposure) untuk menentukan mana rangsangan yang harus di perhatikan dan mana yang harus di abaikan. Menurut Stanton yang dikutip oleh Nugroho J. Setiadi (2010:92) menyatakan bahwa "Persepsi dapat di definisikan sebagai makna yang kita pertalikan berdasarkan pengalaman masa lalu, stimuli 
(rangsangan) yang kita terima melalui lima indra". Menurut Philip Kotler dan Amstrong (2003:218) menyatakan bahwa: "menyatakan bahwa persepsi adalah proses menyeleksi, mengatur, dan menginterpretasikan informasi guna membentuk gambaran yang berarti tentang produk atau jasa".Berdasarkan pengertian ahli diatas, dapat di simpulkan bahwa persepsi adalah makna yang kita pertalikan berdasarkan pengalaman masa lalu, stimuli (rangsangan) yang kita terima melalui lima indra, menyeleksi, mengatur, dan menginterpretasikan informasi guna membentuk gambaran yang berarti tentang dunia. Indikator Persepsi Konsumen, Menurut Stanton yang dikutip oleh Nugroho J. Setiadi (2010:92) dan Philip Kotler dan Amstrong (2003:218) menyebutkan bahwa, indikator persepsi konsumen adalah: Proses menyeleksi, Proses mengatur, Menginterprestasikan informasi, Membentuk gambaran tentang produk. Faktor-faktor yang mempengaruhi Persepsi Konsumen, Menurut Nugroho J. Setiadi (2010:94) menyebutkan bahwa, ada lima faktor yang mempengaruhi persepsi konsumen, yaitu: Warna, Bau, Rasa, Ukuran, Posisi. Karakteristik Konsumen yang memengaruhi persepsi, Menurut Nugroho J. Setiadi (2010:96) persepsi seorang konsumen atas berbagai stimulus yang dipengaruhi oleh karakteristik yang di milikinya. Beberapa karakteristik konsumen yang memengaruhi persepsi sebagai berikut: Membedakan stimulus danTingkat ambang batas (threshold level.

Keputusan Pembelian, Konsumen membuat sejumlah keputusan pembelian setiap hari. Hampir seluruh perusahaan meneliti pengambilan keputusan pembelian konsumen secara mendetil untuk memperoleh jawaban apa yang konsumen beli, dimana mereka membelinya, bagaimana caranya dan seberapa banyak, kapan dan mengapa mereka membelinya. Pemasar dapat mempelajari pembelian konsumen aktual untuk mengetahui apa yang mereka beli, dimana dan berapa banyak. Namun, mempelajari mengenai alasan perilaku pembelian konsumen tidak mudah jawabannya sering kali tersembunyi jauh di dalam benak konsumen., Menurut Schiffman 
dan Kanuk (2008:485) menyatakan bahwa, "Keputusan pembelian adalah seleksi terhadap dua pilihan alternatif atau lebih."Menurut Pride dan Ferrell yang dikutip oleh Sangadji dan Sopiah (2013:332) menyatakan bahwa: "Keputusan pembelian adalah perilaku konsumen akhir, mereka yang membeli suatu produk untuk digunakan secara pribadi, bukan untuk tujuan bisnis atau dijual kembali kepada pihak lain.”. Berdasarkan pengertian ahli diatas, dapat disimpulkan oleh penulis bahwa "Perilaku proses seleksi yang dilakukan konsumen terhadap dua pilihan alternatif atau lebih, mereka yang membeli suatu produk untuk digunakan secara pribadi, bukan untuk tujuan bisnis atau dijual kembali kepada pihak lain.'Indikator Keputusan Pembelian, Berdasarkan hasil kesimpulan maka keputusan pembelian adalah sebagai berikut :Konsumen melakukan seleksi, Konsumen memiliki pilihan alternatif, Konsumen memiliki pembelian akhir, Penggunaan produk secara pribadi. Faktor-faktor yang mempengaruhi Keputusan Pembelian, Menurut Philip Kotler dan Amstrong (2003:200-215) menyebutkan bahwa, keputusan pembelian konsumen dipengaruhi oleh faktor-faktor berikut: Faktor Budaya, Faktor Sosial, Faktor Pribadi, Faktor Psikologi.Proses Pengambilan Keputusan, Menurut Philip Kotler dan Amstrong (2001:224) pemasar harus mengidentifikasi siapa yang membuat keputusan pembelian, jenis-jenis keputusan pembelian, dan langkahlangkah dalam proses pembelian adalah:

Pengenalan kebutuhan

Tahap pertama proses keputusan pembelian dimana konsumen mengenali permasalahan atau kebutuhan.

Pencarian informasi

Tahap proses pengambilan keputusan pembeli dimana konsumen bergerak untuk mencari informasi tambahan, konsumen mungkin sekedar meningkatkan perhatian atau mungkin pula mencari informasi secara aktif Pengevaluasian alternatif

Tahap proses keputusan pembeli dimana konsumen menggunakan informasi untuk mengevaluasi merbagai merek alternatif didalam serangkaian pilihan.

Keputusan pembelian 
Tahap proses keputusan dimana konsumen secara aktual melakukan pembelian produk.

Perilaku setelah pembelian

Tahap proses keputusan pembelian konsumen melakukan tindakan lebih lanjut setelah pembelian berdasarkan pada kepuasan atau tidak puasan mereka.

\section{METODE PENELITIAN}

Metode penelitian yang peneliti gunakan adalah Metode asosiatif. Menurut Sugiyono (2011:8), metode asosiatif adalah metode penelitian yang berlandaskan pada filsafat positivisme, digunakan untuk meneliti pada populasi dan sampel tertentu, pengumpulan data menggunakan instrumen penelitian, analisis data bersifat asosiatif atau statistik, dengan tujuan untuk menguji hipotesis yang telah ditetapkan. Populasi dan Sampel, Menurut Sugiyono (2011:80) menyatakan bahwa "Populasi adalah wilayah generalisasi yang terdiri atas objek atau subjek yang mempunyai kualitas dan karakteristik tertentu yang ditetapkan oleh penelitian untuk dipelajari dan ditarik kesimpulannya" Populasi dalam penelitian ini adalah seluruh konsumen pembeli sepeda motor yamaha pada PT. Permata Motor jatibarang-indramayu yang terdiri dari semua kalangan masyarakat umum Indramayu pada bulan april 2015 sebanyak 200 konsumen.Menurut Sugiyono (2011:81) menyatakan bahwa "Sample adalah bagian dari jumlah dan karakteristik yang dimiliki oleh populasi”. Bila populasi besar dan peneliti tidak dapat mempelajari semua yang ada pada populasi, maka untuk mengetahui berapa sampel yang akan diambil peneliti, yaitu dengan menggunakan rumus Slovin. Untuk menentukan jumlah sampelnya mempergunakan rumus slovin dari Husein Umar (2005:146) yaitu :

$$
n=\frac{N}{1+N \cdot e^{2}}
$$

Dimana:

$\mathrm{n}=$ Ukuran Sampe

$\mathrm{N}=$ Ukuran populasi

$\mathrm{e}=$ Tingkat antisipasi ketidaktelitian karena kesalahan-kesalahan pengambilan sampel yang masih dapat ditolerir atau diinginkan, misalnya $10 \%$.

Jadi jumlah sampel yang akan diambil sebanyak 67 responden.

Operasional Variabel,

Berdasarkan judul yang dikemukakan 
peneliti yaitu pengaruh responsiveness terhadap kepuasan konsumen melalui kualitas pelayanan, maka variabel yang akan digunakan terdiri dari tiga variabel yaitu: variabel bebas (variabel independen), variabel terikat (variabel dependen) dan variabel intervening.Menurut Sugiyono (2011:39) Adapun yang dimaksud dengan variabel independen adalah variabel yang mempengaruhi atau yang menjadi sebab perubahannya atau timbulnya variabel dependen (terikat), kemudian variabel dependen adalah variabel yang dipengaruhi atau menjadi akibat, karena adanya variabel bebas, sedangkan variabel intervening adalah variabel yang secara teoritis mempengaruhi hubungan antara variabel independen dengan dependen menjadi hubungan yang tidak langsung dan tidak dapat diamati dan di ukur. Menurut Sugiyono (2012:93) alat ukur yang digunakan untuk mengukur data yaitu dengan menggunakan Skala Likert, yaitu "Skala Likert digunakan untuk mengukur sikap, pendapat dan persepsi seseorang atau kelompok orang tentang fenomena sosial".Jawaban setiap item instrumen yang menggunakan skala likert mempunyai gradasi dari sangat positif sampai sangat negatif, yang dapat berupa kata-kata dan skor, misalnya: Alat ukur yang digunakan untuk mengukur data yaitu, Skala Likert Menurut Sugiyono (2012:94) yaitu :

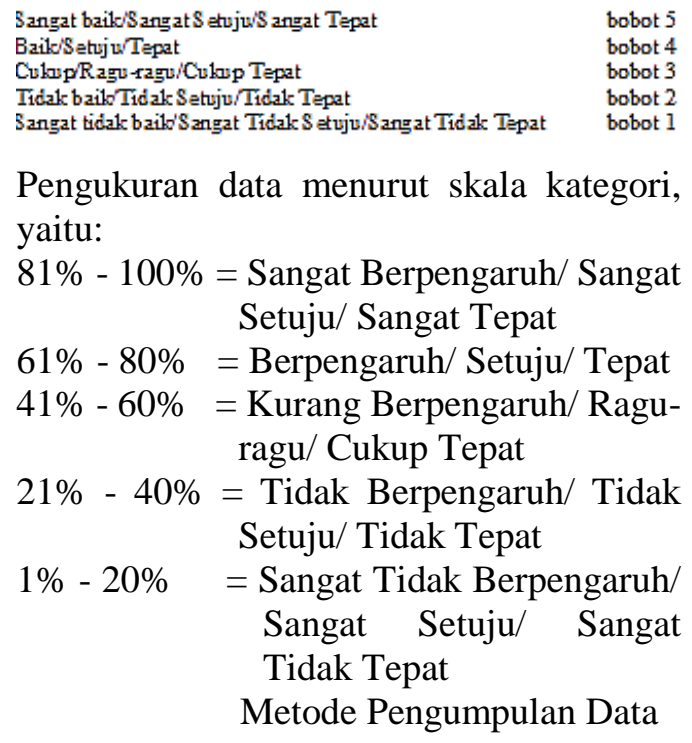

Pengukuran data menurut skala kategori, yaitu:

$81 \%-100 \%=$ Sangat Berpengaruh $/$ Sangat Setuju/ Sangat Tepat

$61 \%-80 \%=$ Berpengaruh $/$ Setuju/ Tepat $41 \%-60 \%=$ Kurang Berpengaruh/ Raguragu/ Cukup Tepat

$21 \%-40 \%=$ Tidak Berpengaruh/ Tidak Setuju/ Tidak Tepat

$1 \%-20 \%=$ Sangat Tidak Berpengaruh $/$ Sangat Setuju/ Sangat Tidak Tepat Metode Pengumpulan Data

Pengumpulan data ini dilakukan dengan cara :

1. Study Kepustakaan (Liberar Research)

Dalam hal ini peneliti mengumpulkan dan mempelajari bukubuku, literatur-literatur serta data-data lainnya yang berhubungan dengan masalah yang diteliti.

\section{Study Lapangan (Field Research)}

Penulis mengadakan penelitian langsung di lapangan untuk memperoleh data yang diperlukan dalam penelitian ini peneliti menggunakan taktik. Metode pengumpulan data dilapangan dapat dilakukan dengan cara: 
a. Quisioner yaitu teknik data dengan cara membuat daftar pertanyaan tertulis disertai dengan jawaban yang telah disediakan oleh penulis dan harus dijawab oleh responden.

b. Inteview (Wawancara) yaitu suatu cara atau taktik untuk mengumpulkan data dengan cara mengadakan tanya jawab serta tatap muka dan langsung dari pihak-pihak yang berwenang, yang ada hubungannya dengan objek yang sedang diamati dan diteliti.

c. Observasi yaitu penelitian yang dilakukan dengan cara mengamati objek secara langsung.

Validitas Instrumen Penelitian, Validitas dalam penelitian menurut Sugiyono (2008:455) adalah "Derajat ketepatan antara data yang sesungguhnya terjadi pada objek penelitian dengan data yang dapat dilaporkan oleh peneliti”. Dengan demikian data yang valid adalah "data yang tidak berbeda" antara data yang dilaporkan oleh peneliti dengan data yang sesungguhnya terjadi pada objek penelitian.

Menurut Sugiyono (2011:125) untuk menguji validitas instrument ada tiga komponen yang harus dilakukan, yaitu:

\section{Pengujian Validitas Konstruksi (Contruct Validity)}

Untuk menguji validitas konstruksi, dapat digunakan pendapat dari ahli (judgment experts). Dalam hal ini setelah instrumen dikonstruksi tentang aspek-aspek yang akan diukur berlandaskan teori tertentu, maka selanjutnya dikonsultasikan dengan para ahli, jumlah tenaga ahli yang digunakan minimal 3 orang dan umumnya mereka yang telah bergelar doktor sesuai dengan yang diteliti. Setelah pengujian konstruksi dari ahli dan berdasarkan pengalaman empiris di lapangan selesai, maka diteruskan denngan uji cobba instrumen. Jumlah anggota sampel yang digunakan sekitar 30 orang. Setelah data ditabulasikan, maka pengujian validitas konstruksi dilakukan dengan analisis faktor, yaitu dengan mengkolerasikan antar skor item instrumen dalah suattu faktor, dan mengkolerasikan skor faktor dengan skor total.

\section{Pengujian Validitas Isi (Content Validity) \\ Untuk instrumen yang berbentuk} test, pengujian validitas ini dapat dilakukan dengan membandingkan antara isi instrumen dengan materi pelajaran yang telah diajarkan. Untuk instrumen yang akan mengukur efektivitas pelaksanaan program, maka pengujian validitas isi dapat dilakukan dengan membandingkan antara isi instrumen dengan isi atau rancangan yang telah ditetapkan.

\section{Pengujian Validitas Eksternal}


Validitas eksternal instrumen diuji dengan cara membandingkan antara kriteria yang ada pada instrumen dengan fakta-fakta empiris yang terjadi dilapangan.

Menurut Sugiyono (2010:228) pengujian validitas instrumen dapat dilakukan dengan rumus korelasi product moment pearson sebagai berikut:

$$
r=\frac{n \sum x y-\left(\sum x\right)\left(\sum y\right)}{\sqrt{\left(n \sum X^{2}-\left(\sum X\right)^{2}\right)\left(n \sum Y^{2}-\left(\sum Y\right)^{2}\right)}}
$$

Dimana:

$\mathrm{r}=$ korelasi product moment person

$\mathrm{n}=$ jumlah data

$\mathrm{x}=$ variabel $\mathrm{X}$

$\mathrm{y}=$ variabel $\mathrm{Y}$

Jika $r_{\text {hitung }}>r_{\text {tabel }}$ maka item disebut valid

Jika $r_{\text {hitung }}<r_{\text {tabel }}$ maka disebut tidak valid

Reliabilitas Instrumen Penelitian, Reliabilitas menurut Husein Umar (2005:194) yaitu yang dipakai untuk menunjukan sejauh mana suatu hasil pengukuran relative konsisten apabila pengukuran diulang dua kali atau lebih". Menurut Sugiyono (2011:130131) pengujian reliabilitas instrumen dapat dilakukan secara eksternal maupun internal. Secara eksternal pengujian dapat dilakukan dengan testretest (stability), equivalent, dan gabungan keguanya. Secara internal reliabilitas instrumen dapat diuji dengan menganalisis konsistensi butir-butir yang ada pada instrumen dengan teknik tertentu.

1. Test-retest

Instrumen penelitian yang reliabilitasnya diuji dengan tetsretest dilakukan dengan cara mencobakan instrumen beberapa kali pada responden. Jika dalam hal ini instrumennya sama, respondennya sama, dan waktunya berbeda. Reliabilitas diukur dari koefisien korelasi antara percobaan pertama dengan yang berikutnya. Bila koefisien korelasi positif dan signifikan maka instrumen tersebut sudah dinyatakan reliable, pengujian ini sering juga disebut stability.

2. Equivalent

Instrumen yang equivalen adalah pertanyaan yang secara bahasa berbeda, tetapi maksudnya sama. Pengujian reliabilitas instrumen dengan cara ini cukup dilakukan sekali, tetapi instrumennya dua, pada responden yang sama, waktu yang sama, instrumen berbeda. Reliabilitas instrumen dihitung dengan cara mengkorelasi antara 
data instrumen yang satu dengan data instrumen yang dijadikan equivalent. Bila korelasi positif dan signifikan, maka instrumen dapat dinyatakan reliable.

\section{Gabungan}

Pengujian reliabilitas ini dilakukan dengan cara mencobakan dua instrumen yang equivalent itu beberapa kali ke responden yang sama. Jadi cara ini merupakan gabungan pertama dan kedua.

Reliabilitas instrumen dilakukan dengan mengkorelasikan dua instrumen, setelah itu dikorelasikan pada pengujian kedua, dan selanjutnya dikorelasikan secara silang.

\section{Internal Consistency}

Pengujian reliabilitas dengan internal consistency, dilakukan dengan cara mencobakan instrumen sekali saja, kemudian yang diperoleh dianalisis dengan teknik tertentu. Hasil analisis dapat digunakan untuk memprediksi reliabilitas instrumen.

Menurut Sugiyono (2011:131) pengujian reliabilitas dapat dilakukan dengan teknik belah dua dari instrumen spearman brown (spilt half) yaitu:

$$
r_{1}=\frac{2 \cdot r_{b}}{1+r_{b}}
$$

Dimana:

$r_{1}=$ reliabilitas internal seluruh instrument

$\mathrm{r}_{\mathrm{b}}=$ korelasi product moment antara belahan pertama dan kedua

Jika $r_{\text {hitung }}>r_{\text {tabel }}$ maka item dinyatakan reliabel.

Jika $r_{\text {hitung }}<r_{\text {tabel }}$ maka item dinyatakan tidak reliabel.

Analisis Jalur, Analisis jalur merupakan teknik statistik yang digunakan untuk menguji hubungan kasual antara dua variabel atau lebih. Esensi dari analisis jalur adalah didasarkan pada sistem persamaan linier. Analisis jalur berbeda dengan teknik analisis regresi, dimana dalam analisi jalur memungkinkan pengujian dengan menggunakan variabel mediating atau intervening. Variabel intervening merupakan pengaruh tidak langsung suatu variabel bebas terhadap variabel tak bebas (terikat) melalui variabel lain yang disebut variabel lain (intervening variabel). Menurut Sugiyono (2012:297) menyatakan bahwa "Analisis jalur (path analysis) merupakan pengembangan dari analisis 
regresi, sehingga analisis regresi dapat dikatakan sebagai bentuk khusus dari analisis jalur (regression is special case of path analysis)". Besarnya pengaruh langsung antara variabel yang mempengaruhi (eksogen) terhadap variabel lain dipengaruhi (endogen) dinyatakan dengan koefisien jalur. Untuk mencari koefisien jalur diperoleh dari persamaan:

$\mathrm{r}_{12}=p_{12}$

$\mathrm{r}_{1 \mathrm{y}}=p_{1 y+} p_{2 y} r_{21}$

$\mathrm{r}_{2 \mathrm{y}}=p_{1 y} r_{21+} p_{2 y}$

Dengan:

$$
\begin{aligned}
& \mathrm{r}_{1 \mathrm{y}}=\frac{n \sum x_{1} y\left(\sum x_{1}\right)\left(\sum y\right)}{\sqrt{\left(n \sum x_{1}^{2}-\left(\sum x_{1}\right)^{2}\right)\left(n \sum y^{2}-\left(\sum y\right)^{2}\right)}} \\
& \mathrm{r}_{2 \mathrm{y}}=\frac{n \sum x_{2} y-\left(\sum x_{2}\right)\left(\sum y\right)}{\sqrt{\left(n \sum x_{2}^{2}-\left(\sum x_{2}\right)^{2}\right)\left(n \sum y^{2}-\left(\sum y\right)^{2}\right)}} \\
& \mathrm{r}_{12}=\frac{n \sum x_{1} x_{2}-\left(\sum x_{1}\right)\left(\sum x_{2}\right)}{\sqrt{\left(n \sum x_{1}^{2}-\left(\sum x_{1}\right)^{2}\right)\left(n \sum x_{2}^{2}-\left(\sum x_{2}\right)^{2}\right)}}
\end{aligned}
$$

Keterangan:

$\mathrm{X}_{1}=$ Citra merek

$\mathrm{X}_{2}=$ Persepsi konsumen

$\mathrm{Y}=$ Keputusan pembelian

$\mathrm{r}_{1 \mathrm{y}}=$ Korelasi Product Moment antara $\mathrm{x}_{1}$ dengan y

$\mathrm{r}_{2 \mathrm{y}}=$ Korelasi Product Moment antara $\mathrm{x}_{2}$ dengan y

$\mathrm{r}_{12}=$ Korelasi Product Moment antara $\mathrm{x}_{1}$ dengan $\mathrm{x}_{2}$

$\mathrm{p}_{1 \mathrm{y}}=$ Nilai Koefisien Jalur $y$ dan $\mathrm{x}_{1}$ $\mathrm{p}_{2 \mathrm{y}}=$ Nilai Koefisien Jalur $y$ dan $\mathrm{x}_{2}$

$\mathrm{p}_{12}=$ Nilai Koefisien Jalur $\mathrm{x}_{1}$ dan $\mathrm{x}_{2}$ Untuk mencari nilai koefisien jalur yaitu, sebagai berikut:

$p_{1 y}=\frac{\left[\begin{array}{cc}r_{y 1} & r_{21} \\ r_{y 2} & 1,00\end{array}\right]}{\left[\begin{array}{cc}1,00 & r_{21} \\ r_{y 2} & 1,00\end{array}\right]}$ dan $p_{2 y}=\frac{\left[\begin{array}{cc}1,00 & r_{y 2} \\ r_{21} & r_{y 2}\end{array}\right]}{\left[\begin{array}{cc}1,00 & r_{21} \\ r_{21} & 1,00\end{array}\right]}$

Analisis Koefisien Korelasi, Dalam menganalisis data peneliti ini menggunakan product momen person untuk mengukur seberapa besar pengaruh citra merek terhadap Keputusan pembelian melalui persepsi konsumen. Menurut Sugyiono (2013:228) pengujian validitas instrument dapat dilakukan dengan rumus Korelasi Product Moment Pearson sebagai berikut:

$$
r=\frac{n \sum x y-\left(\sum x\right)\left(\sum y\right)}{\sqrt{\left(n \sum X^{2}-\left(\sum X\right)^{2}\right)\left(n \sum Y^{2}-\left(\sum Y\right)^{2}\right)}}
$$

Dimana :

$r_{s}=$ Koefisien korelasi product momen pearson

$x, y=$ variabel indikato

$n=$ Jumlah responden

$$
R y(1,2)=\sqrt{\frac{b_{1} \sum x_{1} y+b_{2} \sum x_{2} y}{\sum y^{2}}}
$$

Keterangan.:

$\operatorname{Ry}(1,2)=$ korelasi variabel $\mathrm{X}_{1}, \mathrm{X}_{2}$ dan $\mathrm{Y}$ $\sum \mathrm{x} 1 \mathrm{y}=$ korelasi variabel $\mathrm{X}_{1}$ dengan $\mathrm{Y}$ $\sum \mathrm{x} 1 \mathrm{x} 2=$ korelasi variabel $\mathrm{X}_{1}$ dengan $\mathrm{X}_{2}$ 
$\sum \mathrm{x} 2 \mathrm{y}=$ korelasi variabel $\mathrm{X}_{2}$ dengan $\mathrm{Y}$

Menurut Sugiyono (2013:231) hasil yang didapat diinterpretasikan, sebagai berikut:

\section{Tabel 1}

Pedoman untuk memberikan interprestasi terhadap koefisien korelasi

\begin{tabular}{|cc|c|}
\hline Interval Koefisien & Tingkat Hubungan \\
\hline 0,00 & $-0,199$ & Sangat Rendah \\
\hline 0,200 & $-0,399$ & Rendah \\
\hline 0,400 & $-0,599$ & Sedang \\
\hline 0,600 & $-0,799$ & Kuat \\
\hline 0,800 & $-1,000$ & Sangat Kuat \\
\hline
\end{tabular}

Analisis Koefisien Determinasi, Koefisien determinasi digunakan untuk melihat seberapa besar kontribusi variabel $\mathrm{X}_{1}$ (citra merek) terhadap $\mathrm{Y}$ (keputusan pembelian) melaui $\mathrm{X}_{2}$ (persepsi konsumen). Biasanya dinyatakan dalam persen (\%). Rumus koefisien determinasi sebagai berikut:

Dimana:

$$
k d=r^{2} .100 \%
$$

$\mathrm{Kd}=$ Koefisien Penentu atau Koefisien

\section{Determinasi}

$\mathrm{r}^{2}=$ Koefisien Korelasi

Uji Hipotesis, Menurut Sugiyono (2012:215) mengemukakan bahwa "pengujian hipotesis dimaksudkan sebagai cara untuk menentukan apakah suatu hipotesis tersebut sebaiknya diterima atau ditolak". Dengan menggunakan rumus uji hipotesis sebagai berikut:

$$
t_{h}=r_{s} \sqrt{\frac{n-2}{1-r_{s}^{2}}}
$$

Dimana:

th $=t_{\text {hitung }}$

$\mathrm{r}_{\mathrm{s}}=$ Korelasi Moment Person

$n$ = Responden

\section{HASIL DAN PEMBAHASAN}

Validitas Instrument Citra Merek

Tabel .2

Rekapitulasi Validitas Instrumen

\begin{tabular}{|c|c|c|c|}
\hline \multirow[b]{2}{*}{$\begin{array}{c}\text { Nomor } \\
\text { Pertanya } \\
\text { an }\end{array}$} & \multicolumn{2}{|c|}{ Validitas } & \multirow[b]{2}{*}{$\begin{array}{c}\text { Kesimpul } \\
\text { an }\end{array}$} \\
\hline & $\begin{array}{c}\text { Koefisi } \\
\text { en } \\
\text { Korelas } \\
\text { i } \\
\text { (r } \\
\text { hitung) }\end{array}$ & $\begin{array}{c}\text { Nilai } \\
\text { Kritis (r } \\
\text { tabel } \\
\text { dengan } \\
\text { taraf } \\
\text { signifik } \\
\text { an 5\%) }\end{array}$ & \\
\hline 1 & 0,554 & 0,244 & Valid \\
\hline 2 & 0,513 & 0,244 & Valid \\
\hline 3 & 0,429 & 0,244 & Valid \\
\hline 4 & 0,470 & 0,244 & Valid \\
\hline 5 & 0,555 & 0,244 & Valid \\
\hline 6 & 0,380 & 0,244 & Valid \\
\hline 7 & 0,400 & 0,244 & Valid \\
\hline 8 & 0,473 & 0,244 & Valid \\
\hline 9 & 0,458 & 0,244 & Valid \\
\hline 10 & 0,460 & 0,244 & Valid \\
\hline
\end{tabular}
Penelitian Citra Merek

Dengan $r$ tabel 0,244 indikasi 5\% dan jumlah responden 67 di peroleh data diatas. Dari tabel diatas terlihat bahwa 10 pertanyaan $r$ hitungnya $>$ dari $r$ table 0,244 jadi semua pertanyaan Valid dan dapat digunakan dalam analisa berikutnya. 


\section{Validitas Instrument Persepsi \\ Konsumen}

Tabel 3

Rekapitulasi Validitas Instrumen Persepsi Konsumen

\begin{tabular}{|c|c|c|c|}
\hline \multirow[b]{2}{*}{$\begin{array}{c}\text { Nomor } \\
\text { Pertanya } \\
\text { an }\end{array}$} & \multicolumn{2}{|c|}{ Validitas } & \multirow[b]{2}{*}{$\begin{array}{c}\text { Kesimpul } \\
\text { an }\end{array}$} \\
\hline & $\begin{array}{c}\text { Koefisi } \\
\text { en } \\
\text { Korelas } \\
\text { i } \\
\text { (r } \\
\text { hitung) }\end{array}$ & $\begin{array}{l}\text { Nilai } \\
\text { Kritis (r } \\
\text { tabel } \\
\text { dengan } \\
\text { taraf } \\
\text { signifik } \\
\text { an 5\%) }\end{array}$ & \\
\hline 1 & 0,592 & 0,244 & Valid \\
\hline 2 & 0,370 & 0,244 & Valid \\
\hline 3 & 0,443 & 0,244 & Valid \\
\hline 4 & 0,411 & 0,244 & Valid \\
\hline 5 & 0,485 & 0,244 & Valid \\
\hline 6 & 0,257 & 0,244 & Valid \\
\hline 7 & 0,448 & 0,244 & Valid \\
\hline 8 & 0,620 & 0,244 & Valid \\
\hline
\end{tabular}

Dengan $r$ table 0,244 indikasi 5\%

dan jumlah responden 67 di peroleh data diatas. Dari tabel diatas terlihat bahwa 8 pertanyaan $r$ hitungnya $>$ dari $r$ table 0,244 jadi semua pertanyaan Valid dan dapat digunakan dalam analisa berikutnya.

Validitas Instrument Keputusan Pembelian

Tabel 4

Rekapitulasi Validitas Instrumen Penelitian keputusan pembelian

\begin{tabular}{|c|c|c|c|}
\hline \multirow{2}{*}{$\begin{array}{c}\text { Nomor } \\
\text { Pertanya } \\
\text { an }\end{array}$} & $\begin{array}{c}\text { Koefisi } \\
\text { en } \\
\text { Korelas } \\
\mathrm{i} \\
\text { (r } \\
\text { hitung) }\end{array}$ & $\begin{array}{c}\text { Nilai } \\
\text { Kritis (r } \\
\text { tabel } \\
\text { dengan } \\
\text { taraf } \\
\text { signifik } \\
\text { an 5\%) }\end{array}$ & \multirow{2}{*}{$\begin{array}{c}\text { Kesimpul } \\
\text { an }\end{array}$} \\
\hline 1 & 0.470 & 0,244 & Valid \\
\hline 2 & 0.521 & 0,244 & Valid \\
\hline 3 & 0,393 & 0,244 & Valid \\
\hline
\end{tabular}

\begin{tabular}{|l|l|l|l|}
\hline 4 & 0,703 & 0,244 & Valid \\
\hline 5 & 0,616 & 0,244 & Valid \\
\hline 6 & 0,250 & 0,244 & Valid \\
\hline 7 & 0,637 & 0,244 & Valid \\
\hline 8 & 0,539 & 0,244 & Valid \\
\hline
\end{tabular}

Dengan $r$ table 0,244 indikasi 5\% dan jumlah responden 67 di peroleh data diatas. Dari tabel diatas terlihat bahwa 8 pertanyaan $\mathrm{r}$ hitungnya $>$ dari $\mathrm{r}$ table 0,244 jadi semua pertanyaan Valid dan dapat digunakan dalam analisa berikutnya.

Reliabilitas Instrument Citra Merek,

Perhitungan reliabilitas instrumen citra merek diperoleh dari hasil angket citra merek yang telah dihitung validitasnya yaitu:

$r=\frac{67.27416-(1352)(1354)}{\sqrt{\left[67.27428-(1352)^{2}\right]\left[\left(67.27528-(1354)^{2}\right]\right.}}$

$r=0,514$

Dari hasil korelasi diatas maka dihitung:

$r_{i}=\frac{2 \cdot(0,514)}{1+(0,514)} \quad r_{i}=0,679$

Dari penghasilan penghitungan reliabilitas angket citra merek diperoleh $r=0,679$ dengan $\mathrm{n}=67$ dan taraf signifikan 5\% didapat $r$ tabel $=0,244$ sehingga $r$ hitung > $r$ tabel $(0,679>$ $0,244)$ maka dapat disimpulkan bahwa angket citra merek reliabel.

Reliabilitas Instrument Persepsi Konsumen

Perhitungan

instrument persepsi reliabilitas

konsumen 
diperoleh dari hasil angket persepsi konsumen yang telah dihitung validitasnya yaitu:

$$
\begin{aligned}
r & =\frac{67.17988-(1120)(1072)}{\sqrt{\left[67.18892-(1120)^{2}\right]\left[\left(67.17988-(1072)^{2}\right]\right.}} \\
r & =0.432
\end{aligned}
$$

Dari hasil korelasi diatas maka dihitung:

$r_{i}=\frac{2 \cdot(0,432)}{1+(0,432)} \quad r_{i}=0,603$

Dari penghasilan penghitungan reliabilitas angket Komunikasi diperoleh $r=0,603$ dengan $\mathrm{n}=67$ dan taraf signifikan $5 \%$ didapat $r$ tabel $=$ 0,244 sehingga $r$ hitung $>$ r tabel $(0,603$ $>$ 0,244) maka dapat disimpulkan bahwa angket persepsi konsumen reliabel.

Reliabilitas Instrument Keputusan Pembelian

\section{Perhitungan} reliabilitas instrument keputusan pembelian diperoleh dari hasil angket keputusan pembelian yang telah dihitung validitasnya yaitu:

$$
\begin{aligned}
& r=\frac{67.17323-(1085)(1065)}{\sqrt{\left[67.17711-(1085)^{2}\right]\left[\left(67.17071-(1065)^{2}\right]\right.}} \\
& r=0.540
\end{aligned}
$$

Dari hasil korelasi diatas maka dihitung:

$$
r_{i}=\frac{2 \cdot(0,540)}{1+(0,540)} \quad r_{i}=0,70
$$

Dari penghasilan penghitungan reliabilitas angket persepsi konsumen diperoleh $\quad r=0,70$ dengan $N=67$ dan taraf signifikan $5 \%$ didapat $r$ tabel $=$ 0,244 sehingga $r$ hitung $>r$ tabel $(0,70$ $>$ 0,244) maka dapat disimpulkan bahwa angket keputusan pembelian reliabel.

Persamaan Regresi

Persamaan regresi dua prediktor:

$\sum \mathrm{Y}=\mathrm{an}+\mathrm{b}_{1} \sum \mathrm{X}_{1}+\mathrm{b}_{2} \sum \mathrm{X}_{2}$

$\sum \mathrm{X}_{1} \mathrm{Y}=\mathrm{a} \sum \mathrm{X}_{1}+\mathrm{b}_{1} \sum \mathrm{X}_{1}^{2}+\mathrm{b}_{2} \sum \mathrm{X}_{1} \mathrm{X}_{2}$

$\sum \mathrm{X}_{2} \mathrm{Y}=\mathrm{a} \sum \mathrm{X}_{2}+\mathrm{b}_{1} \sum \mathrm{X}_{1} \mathrm{X}_{2}+\mathrm{b}_{2} \sum \mathrm{X}_{2}^{2}$

Subtitusi nilai-nilai dari tabel penolong ke dalam persamaan

$2150=67 a+2706 b_{1}+2192 b_{2}$

$87147=2706 \mathrm{a}+109842 \mathrm{~b}_{1}+88745 \mathrm{~b}_{2}$

$70514=2192 a+88745 b_{1}+72166 b_{2}$

Dari persamaan (1) dan (2) eliminasi a

$2150=67 \mathrm{a}+2706 \mathrm{~b}_{1}+2192 \mathrm{~b}_{2} \quad \mathrm{x} 2706$ $87147=2706 a+109842 b_{1}+88745 b_{2} \times 67$

Maka,

$5817900=181302 \mathrm{a}+7322436 \mathrm{~b}_{1}+5931552 \mathrm{~b}_{2}$ $5838849=181302 a+7359414 b_{1}+5945915 b_{2}$

Didapatkan

$-20949=-36978 b_{1}-14363 b 2$

setiap ruas dikali (-)

$20949=36978 b_{1}+14363 b_{2}$

Eliminasi a dari persamaan (1) dan (3)

$2150=67 a+2706 b_{1}+2192 b_{2} \quad x 2192$ $70514=2192 a+88745 b_{1}+72166 b_{2} \times 67$

Maka,

$4712800=146864 \mathrm{a}+5931552 \mathrm{~b}_{1}+4804864 \mathrm{~b}_{2}$ $4724438=146864 a+5945915 b_{1}+4835122 b_{2}$

Didapatkan 
$-11638=-14363 b_{1}-30258 b_{2}$ setiap ruas dikali (-)

$11638=14363 b_{1}+30258 b_{2}$

Dari persamaan (4) dan (5) eliminasi $b_{1}$ untuk mendapatkan $\mathrm{b}_{2}$

$$
\begin{array}{ll}
20949=36978 b_{1}+14363 b_{2} & \times 14363 \\
11638=14363 b_{1}+30258 b_{2} & \times 36978
\end{array}
$$

Maka,

$$
\begin{aligned}
& 300890487=531115014 b_{1}+206295769 b_{2} \\
& 430349964=531115014 b_{1}+1118880324 b_{2} \\
& \text { Didapatkan } \\
& -129459477=-912584555 b_{2} \\
& -912584555 b_{2}=-129459477 \\
& b_{2}=-129459477 /-912584555=0,142
\end{aligned}
$$

Nilai $b_{2}$ disubtitusikan dalam salah satu persamaan (4) untuk mendapatkan nilai $b_{1}$ $20949=36978 b_{1}+14363 b_{2}$ $20949=36978 b_{1}+14363(0,142)$

$20949=36978 b_{1}+2039,546$

$36978 b_{1}=20949-2039,546$

$36978 b_{1}=18909,45$

$b_{1}=18909,45 / 36978=0,511$

Nilai $b_{1}=0,511$ dan $b_{2}=0,142$ subtitusi ke persamaan (1) untuk mendapatkan nilai a $2150=67 a+2706 b_{1}+2192 b_{2}$ $2150=67 \mathrm{a}+2706(0,511)+2192(0,142)$

$2150=67 \mathrm{a}+1382,766+311,264$

$2150=67 \mathrm{a}+1694,03$

$67 \mathrm{a}=2150-1694,03$

$67 \mathrm{a}=455,97$

$a=455,97 / 67=6,805$

Jadi,

$\mathrm{a}=6,805$

$\mathrm{b}_{1}=0,511$ $\mathrm{b}_{2}=0,142$

Setelah nilai $a, b_{1}$, dan $b_{2}$ didapat, maka persamaan regresi:

$Y=6,805+0,511 X_{1}+0,142 X_{2}$

Menentukan Korelasi Berganda

$\mathrm{R}_{\mathrm{y}(1,2)}=\sqrt{\frac{\mathrm{b}_{1} \sum \mathrm{x}_{1} \mathrm{y}+\mathrm{b}_{2} \sum \mathrm{x}_{2} \mathrm{y}}{\sum \mathrm{y}^{2}}}$

Setelah diketahui $b_{1}=0,511$ dan $b_{2}=$ 0,142

Maka,

$$
\begin{aligned}
R_{y(1,2)} & =\sqrt{\frac{(0,511) 87147+(0,142) 70514}{69428}} \\
R_{y(1,2)} & =\sqrt{\frac{44532,12+10012,99}{69428}} \\
& =\sqrt{\frac{54545,11}{69428}}=\sqrt{0,786} \\
R_{y(1,2)} & =0,886
\end{aligned}
$$

Dari perhitungan diatas diperoleh $r \neq 0$ yakni 0,886 artinya citra merek berpengaruh terhadap keputusan pembelian dan dikatakan dalam katagori sangat kuat.

Analisis Jalur

Untuk mencari koefisien jalur diperoleh dari persamaan

$\mathrm{r}_{21}=\mathrm{p}_{12}$

$\mathrm{r}_{\mathrm{y} 1}=\mathrm{p}_{1 \mathrm{y}}+\mathrm{p}_{2 \mathrm{y}} \cdot \mathrm{r}_{21}$

$r_{y 2}=p_{1 y} \cdot r_{21}+p_{2 y}$

Korelasi $\mathrm{X}_{1}$ dengan $\mathrm{X}_{2}$

$r_{12}=\frac{n \sum x_{1} x_{2}-\sum x_{1} \sum x_{2}}{\sqrt{\left(n \sum x_{1}{ }^{2}-\left(\sum x_{1}\right)^{2}\right)\left(n \sum x_{2}{ }^{2}-\left(\sum x_{2}\right)^{2}\right)}}$

$r_{12}=\frac{67.88745-(2706)(2192)}{\sqrt{\left(67.109842^{2}-(2706)^{2}\right)\left(67.72166^{2}-(2192)^{2}\right)}}$

$\mathbf{r}_{12}=0,429$

Korelasi $\mathrm{X}_{1}$ dengan $\mathrm{Y}$ 


$$
\begin{aligned}
& r_{1 y}=\frac{n \sum x_{1} y-\sum x_{1} \sum y}{\sqrt{\left(n \sum x_{1}{ }^{2}-\left(\sum x_{1}\right)^{2}\right)\left(n \sum y^{2}-\left(\sum y\right)^{2}\right)}} \\
& r_{1 y}=\frac{67.87147-(2706)(2150)}{\sqrt{\left(67.109842^{2}-(2706)^{2}\right)\left(67.69428^{2}-(2150)^{2}\right)}} \\
& r_{1 y}=0,638
\end{aligned}
$$

Korelasi $\mathrm{X}_{2}$ dengan $\mathrm{Y}$

$$
\begin{aligned}
& \mathrm{r}_{2 \mathrm{y}}=\frac{n \sum x_{2} y-\sum x_{2} \sum y}{\sqrt{\left(n \sum x_{2}{ }^{2}-\left(\sum x_{2}\right)^{2}\right)\left(n \sum y^{2}-\left(\sum y\right)^{2}\right)}} \\
& \mathrm{r}_{2 \mathrm{y}}=\frac{67.70514-(2192)(2150)}{\sqrt{\left(67.72166^{2}-(2192)^{2}\right)\left(67.69428^{2}-(2150)^{2}\right)}} \\
& \mathrm{r}_{2 \mathrm{y}}=0,392
\end{aligned}
$$

Sehingga,

$$
\begin{aligned}
0,429 & =\mathrm{p}_{12} \\
0,638 & =\mathrm{p}_{1 \mathrm{y}}+\mathrm{p}_{2 \mathrm{y}} \cdot(0,429) \\
0,392 & =\mathrm{p}_{1 \mathrm{y}} \cdot(0,429)+\mathrm{p}_{2 \mathrm{y}}
\end{aligned}
$$

Mencari Nilai Koefisien Jalur $\mathrm{p}_{1 \mathrm{y}}$

$$
\begin{aligned}
\mathrm{p}_{1 y} & =\frac{\left[\begin{array}{ll}
r_{1 y} & r_{12} \\
r_{2 y} & 1,00
\end{array}\right]}{\left[\begin{array}{cc}
1,00 & r_{12} \\
r_{12} & 1,00
\end{array}\right]} \\
\mathrm{p}_{1 \mathrm{y}} & =\frac{\left[\begin{array}{ll}
0,638 & 0,429 \\
0,392 & 1,000
\end{array}\right]}{\left[\begin{array}{ll}
1,000 & 0,429 \\
0,429 & 1,000
\end{array}\right]} \\
\mathrm{p}_{1 \mathrm{y}} & =\frac{[(0,639 \times 1,000)-(0,429 \times 0,392)]}{[(1,000 \times 1,000)-(0,429 \times 0,429)]} \\
\mathrm{p}_{1 \mathrm{y}} & =\frac{[(0,639)-(0.168)]}{[(1,000)-(0,184)]} \\
\mathrm{p}_{1 \mathrm{y}} & =\frac{[0,471]}{[0,816]} \\
\mathrm{p}_{1 \mathrm{y}} & =0,577
\end{aligned}
$$

Mencari Nilai Koefisien Jalur $\mathrm{p}_{2 \mathrm{y}}$

$$
\begin{aligned}
& \mathrm{p}_{2 y}=\frac{\left[\begin{array}{ll}
1,00 & r_{1 y} \\
r_{12} & r_{2 y}
\end{array}\right]}{\left[\begin{array}{cc}
1,00 & r_{12} \\
r_{12} & 1,00
\end{array}\right]} \\
& \mathrm{p}_{2 y}=\frac{\left[\begin{array}{cc}
1,00 & 0,638 \\
0.429 & 0,392
\end{array}\right]}{\left[\begin{array}{ll}
1,000 & 0,429 \\
0,429 & 1,000
\end{array}\right]} \\
& \mathrm{p}_{2 y}=\frac{[(1,000 x 0,392)-(0,429 \times 0,638)]}{[(1,000 \times 1,000)-(0,429 \times 0,429)]} \\
& \mathrm{p}_{2 y}= \frac{[(0,392)-(0,274)]}{[(1,000)-(0,184)]} \\
& \mathrm{p}_{2 y}= \frac{[0.118]}{[0,816]} \\
& \mathrm{p}_{2 \mathrm{y}}=0,145
\end{aligned}
$$

Gambar .1

Analisis Jalur $\mathrm{X}_{1}$ Terhadap Y melalui $\mathrm{X}_{2}$

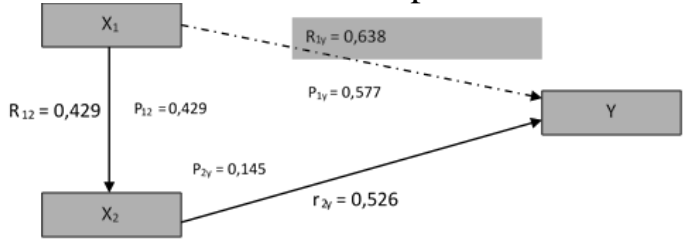

Korelasi $\mathrm{X}_{1}$ terhadap Y melalui $\mathrm{X}_{2}$

$P_{\text {intervening }}=\mathrm{p}_{1 \mathrm{y}}+\mathrm{p}_{2 \mathrm{y}} \cdot \mathrm{r}_{12}$

$\mathrm{P}_{\text {intervening }}=0,577+0,145(0,429)$

$P_{\text {intervening }}=0,577+0,062$

$P_{\text {intervening }}=0,639$

Dari perhitungan diatas diperoleh $\mathrm{P}_{\text {intervening }}=0,639$ artinya citra merek terhadap keputusan pembelian melalui persepsi konsumen pada PT. Permata motor jatibarang berpengaruh dan termasuk dalam kategori kuat.

\section{Analisis Koefisien Determinasi}

Koefisien Determinasi $\mathrm{X}_{1}$ terhadap $\mathrm{X}_{2}$

$$
\begin{aligned}
& \mathrm{Kd}=\left(\mathrm{r}_{12}\right)^{2} \times 100 \% \\
& \mathrm{Kd}=18,40 \%
\end{aligned}
$$

Berdasarkan perhitungan diatas dapat disimpulkan bahwa, citra merek terhadap persepsi konsumen memiliki kontribusi sebesar 18,40\% Sedangkan sisanya $81,60 \%$ dipengaruhi oleh faktor-faktor lainnya yang tidak diteliti.

Koefisien Determinasi $\mathrm{X}_{2}$ terhadap Y

$$
\begin{aligned}
& \mathrm{Kd}=\left(\mathrm{r}_{2 \mathrm{y}}\right)^{2} \times 100 \% \\
& \mathrm{Kd}=27,66 \%
\end{aligned}
$$


Berdasarkan perhitungan diatas dapat disimpulkan bahwa, persepsi konsumen terhadap keputusan pembelian memiliki kontribusi sebesar $27,66 \%$ Sedangkan sisanya $72,34 \%$ dipengaruhi oleh faktor-faktor lainnya yang tidak diteliti.

Koefisien Determinasi $\mathrm{X}_{1}$ terhadap Y melalui $\mathrm{X}_{2}$.

$\mathrm{Kd}=(\mathrm{r})^{2} \times 100 \%$

$\mathrm{Kd}=40,88 \%$

Berdasarkan perhitungan diatas dapat disimpulkan bahwa, citra merek terhadap keputusan pembelian melalui persepsi konsumen memiliki kontribusi sebesar 40,88\% Sedangkan sisanya $59,12 \%$ dipengaruhi oleh faktor-faktor lainnya yang tidak diteliti.

Uji Hipotesis

Hipotesis $\mathrm{X}_{1}$ terhadap $\mathrm{X} 2$

$$
\begin{aligned}
\text { th } & =r \sqrt{\frac{n-2}{1-\mathrm{r}^{2}}} \\
\text { th } & =3,829
\end{aligned}
$$

Berdasarkan hasil perhitungan diatas diperoleh $\mathrm{t}$ hitung $=3,829$ sedangkan $t$ tabel dengan taraf keyakinan $5 \%$ dan derajat kebebasan $\mathrm{dk}=\mathrm{n}-2=67-2=65$, maka $\mathrm{t}$ hitung $=$ 3,829 Karena t hitung lebih besar dari $t$ tabel yaitu sebesar $(3,829>1,997)$, maka Ha diterima dan Ho ditolak, artinya "ada pengaruh citra merek terhadap persepsi konsumen"

\section{Gambar 2}

Kurva Hipotesis uji dua pihak $\mathrm{X}_{1}$ terhadap $\mathrm{X} 2$

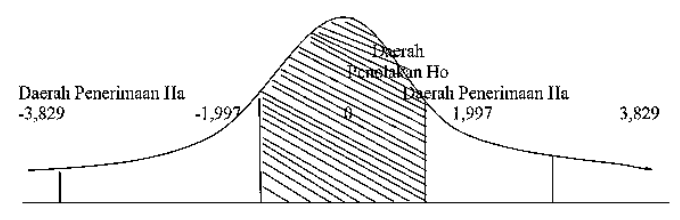

Hipotesis $\mathrm{X}_{2}$ terhadap $\mathrm{Y}$

th $=r \sqrt{\frac{n-2}{1-\mathrm{r}^{2}}}$

th $=3,436$

Berdasarkan hasil perhitungan diatas diperoleh $\mathrm{t}$ hitung $=3,436$ sedangkan $t$ tabel dengan taraf keyakinan $5 \%$ dan derajat kebebasan $\mathrm{dk}=\mathrm{n}-2=67-2=65$, maka $\mathrm{t}$ table $=3,436$ Karena t hitung lebih besar dari t tabel yaitu sebesar (3,436 > 1,997), maka Ha diterima dan Ho ditolak, artinya "ada pengaruh keputusan pembelian terhadap persepsi konsumen"

Gambar 3

Kurva Hipotesis uji dua pihak $\mathrm{X}_{2}$ terhadap Y

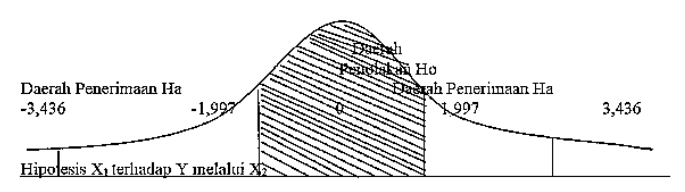

Berdasarkan hasil perhitungan diatas diperoleh $\mathrm{t}$ hitung $=6,695$ sedangkan $t$ tabel dengan taraf 
keyakinan 5\% dan derajat kebebasan $\mathrm{dk}=\mathrm{n}-2=67-2=65$, maka $\mathrm{t}$ table $=6,695$ Karena $\mathrm{t}$ hitung lebih besar dari $\mathrm{t}$ tabel yaitu sebesar $(6,695>1,997)$, maka $\mathrm{Ha}$ diterima dan Ho ditolak, artinya "ada pengaruh citra merek terhadap persepsi konsumen melalui keputusan pembelian"

$$
\text { Gambar } 4
$$

Kurva Hipotesis uji dua pihak $\mathrm{X}_{1}$ terhadap $\mathrm{Y}$ melalui $\mathrm{X}_{2}$

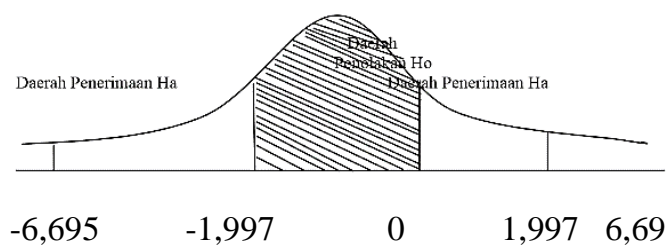

\section{KESIMPULAN DAN SARAN}

\section{Kesimpulan}

1. Citra merek merupakan faktor yang sangat penting bagi PT. Permata Motor Jatibarang. Hal ini terlihat dari jumlah skor yang diberikan responden terhadap citra merek sebesar $80,77 \%$ dengan klasifikasi "Sangat Setuju"

2. Persepsi konsumen yang ada dikonsumen PT. Permata Motor Jatibarang dapat mempengaruhi konsumen untuk melakukan pembelian. Hal ini terlihat dari jumlah skor yang diberikan responden terhadap persepsi konsumen sebesar $81,79 \%$ dengan klasifikasi "Sangat Setuju"
3. Keputusan Pembelian yang dilakukan oleh konsumen Motor Yamaha di PT. Permata Motor Jatibarang sangat mempengaruhi konsumen untuk melakukan pembelian. Hal ini terlihat dari jumlah skor yang diberikan responden terhadap Keputsasan pembelian sebesar 80,22\% dengan klasifikasi "Sangat Setuju"

4. Hasil analisis korelasi citra merek terhadap persepsi konsumen adalah korelasi $\mathrm{r}_{12}=0,429$ membuktikan bahwa terdapat pengaruh citra merek terhadap persepsi konsumen dengan kategori sedang. Hasil analisis determinasinya adalah $\mathrm{Kd}=18,40 \%$ berarti citra merek memiliki kontribusi terhadap persepsi konsumen sebesar $18,40 \%$ Sedangkan sisanya $81,60 \%$ dipengaruhi oleh faktor-faktor lainnya yang tidak diteliti. Dan hasil uji hipotesisnya adalah th $=3,829$ sedangkan $t$ tabel dengan taraf keyakinan 5\% dan derajat kebebasan $\mathrm{dk}=\mathrm{n}-2=67-2=65$, maka $\mathrm{t}$ hitung $=$ 3,829 Karena t hitung lebih besar dari t tabel yaitu sebesar $(3,829>$ 1,997), maka Ha diterima dan Ho 
Nandan A Hidayat, M. Arif Hasan

ditolak, artinya "ada pengaruh citra merek terhadap persepsi konsumen"

5. Hasil analisis korelasi antara persepsi konsumen dengan keputusan pembelian adalah korelasi $\mathrm{r}_{2 \mathrm{y}}=0,392$ membuktikan bahwa terdapat pengaruh persepsi konsumen terhadap keputusan pembelian dengan kategori rendah. Hasil analisis determinasinya adalah $\mathrm{Kd}=$ $27,66 \%$ berarti persepsi konsumen memiliki kontribusi terhadap keputusan pembelian sebesar $27,66 \%$ Sedangkan sisanya $72,34 \%$ dipengaruhi oleh faktor-faktor lainnya yang tidak diteliti. Dan hasil uji hipotesisnya adalah th $=3,436$ sedangkan $\mathrm{t}$ tabel dengan taraf keyakinan 5\% dan derajat kebebasan $\mathrm{dk}=\mathrm{n}-2=67-2=65$, maka $\mathrm{t}$ table $=$ 3,436 Karena t hitung lebih besar dari t tabel yaitu sebesar $(3,436>$ 1,997), maka Ha diterima dan Ho ditolak, artinya "ada pengaruh keputusan pembelian terhadap persepsi konsumen"

6. Hasil analisis korelasi citra merek terhadap keputusan pembelian melalui motivasi adalah korelasi $\mathrm{r}_{12 \mathrm{y}}$ $=0,639$ membuktikan bahwa terdapat pengaruh citra merek terhadap keputusan pembelian melalui persepsi konsumen dengan kategori kuat. Hasil analisis determinasinya adalah $\mathrm{Kd}=40,88 \%$ berarti citra merek terhadap keputusan pembelian melalui persepsi konsumen memiliki kontribusi sebesar $\quad 40,88 \%$ Sedangkan sisanya $59,12 \%$ dipengaruhi oleh faktor-faktor lainnya yang tidak diteliti. Dan hasil uji hipotesisnya adalah th $=6,695$ sedangkan $t$ tabel dengan taraf keyakinan 5\% dan derajat kebebasan $\mathrm{dk}=\mathrm{n}-2=67-2=65$, maka $\mathrm{t}$ table $=$ 6,695 Karena t hitung lebih besar dari t tabel yaitu sebesar $(6,695>$ 1,997), maka Ha diterima dan Ho ditolak, artinya "ada pengaruh citra merek terhadap persepsi konsumen melalui keputusan pembelian"

\section{Saran}

Berdasarkan hasil penelitian tersebut, penulis memberikan saransaran yaitu sebagai berikut:

1. Perusahaan harus mempertahankan tingkat penjualan dengan mempertahankan citra merek, supaya konsumen tidak meninggalkan merek tersebut. 
2. Perusahaan harus mempertahankan tingkat penjualan dengan melihat persepsi konsumennya.

3. Perusahaan harus mempertahankan tingkat penjualan dengan melihat keputusan pembelian konsumennya, karena Keputusan pembelian merupakan tujuan akhir dari perusahaan.

4. Bagi perusahaan, citra merek harus diperhatikan perusahaan untuk meningkatkan keputusan pembelian skuter matic di PT. Permata Motor Jatibarang.

5. Persepsi konsumen harus diperhatikan perusahaan untuk meningkatkan keputusan pembelian skuter matic di PT. permata Motor Jatibarang.

6. Perusahaan Keputusan pembelian merupakan tujuan akhir dari perusahaan oleh karena itu perusahaan dituntut untuk membuat konsumen membeli motor Yamaha di PT. Permata Motor Jatibarang.

\section{DAFTAR PUSTAKA}

Kanuk, schiffman. 2006. Perilaku konsumen. Indeks. Jakarta

Kanuk, Schiffman. 2008. Perilaku Konsumen Edisi ke 7. PT. Macanan Jaya Cemerlang., Bandung

Kotler \& armstrong. 2003. Dasar-dasar pemasaran. PT indeks kelompok gramedia

Kotler, Philip dan Kevin Keller. 2009. Manajemen Pemasaran. Jilid 1. Edisi ke 13. Diterjemahkan oleh Bob Sabran. Jakarta: Erlangga.

Sangadji, Etta. 2013. Perilaku Konsumen. Andi., Yogyakarta.

Setiadi, nugroho. 2010. Perilaku konsumen. Kencana. Jakarta

Sugiyono, 2012. Statistik untuk Penelitian. Alfabet, BandunG

Sumarwan, ujang. 2009. Pemasaran strategik. Inti prima promosindo., Jakarta.

Sugiyono. 2011. Metode Penelitian Kuantitatif Kualitatif dan $R \& D$. Alfabeta. Bandung

Umar, Husein. 2005. Metode Penelitian untuk Skripsi dan Tesis. Gramedia Pustaka Utama. Jakarta 